\title{
Przepełniony miłością w myśleniu i działaniu
}

KARDYNAE STANISEAW DZIWISZ

Metropolita Krakowski

Panie Rektorze,

Księże Rektorze,

Drodzy Organizatorzy konferencji,

Szanowni Państwo,

„W młodym wieku odszedł do Pana wybitny Pasterz" - tak napisał w telegramie kondolencyjnym o zmarłym 10 lutego 2011 roku w Rzymie Arcybiskupie Józefie Życińskim papież Benedykt XVI. Słowa papieskie stanowią doskonałe streszczenie życia i działalności Arcybiskupa. Była to postać bogata i wielowymiarowa, niemieszcząca się w schematach i utartych formułach. Arcybiskup Życiński był człowiekiem dialogu, a w tym dialogu promował otwartość. Jakże aktualne są jego słowa, iż „początkiem dramatu jest przekonanie, że jesteśmy lepsi, więcej wiemy. Chrystus powiedział: «Wy jesteście światłem świata». Ale nie sugerował, że reszta to mrok"1. Dlatego w epoce platonicznej nieżyczliwości

1 J. Życiński, Świat musi mieć sens. Przerwana rozmowa arcybiskupa Józefa Życińskiego i Aleksandry Klich, Warszawa 2012, s. 47. 
i wzajemnych pomówień warto na nowo odnaleźć Chrystusowy styl przepowiadania i debatowania, przepełniony miłością już w myśleniu, a potem w działaniu.

Szanowni Państwo, głęboka wiara Arcybiskupa Józefa Życińskiego pozwalała na dowartościowywanie chrześcijańskiej solidarności ducha, w której szanuje się godność bez patosu i promuje miłość bez urazy. Chrystusowy styl duszpasterzowania wybitnego pasterza na każdej płaszczyźnie był dowartościowany w wielu środowiskach - w Papieskiej Radzie do spraw Kultury i w Europejskiej Akademii Nauki i Sztuki w Salzburgu. Również Uniwersytet Jagielloński dowartościował jego postawę doktoratem honoris causa w 2005 roku.

W tym kontekście cieszę się z otwarcia ogólnopolskiej konferencji naukowej Media - Kultura - Dialog. W piata rocznicę śmierci arcybiskupa Józefa Życińskiego zorganizowanej przez Uniwersytet Jagielloński, którego był doktorem honoris causa, Uniwersytet Papieski Jana Pawła II, którego był profesorem, Naczelną Radę Adwokacką w Warszawie i Okręgową Radę Adwokacką w Krakowie, do której nieraz przemawiał i przez którą został dowartościowany najwyższym odznaczeniem, a także Akademię Ignatianum, w której prezentował słynną publikację kardynała Ratzingera Patrzeć na Chrystusa.

Pragnę podziękować Jego Magnificencji, Panu Rektorowi Wojciechowi Nowakowi, Komitetowi Organizacyjnemu w osobach - ks. Roberta Nęcka, mojego rzecznika 
prasowego, który był uczniem Arcybiskupa, pracownika naukowego Instytutu Dziennikarstwa i Komunikacji Społecznej Uniwersytetu Papieskiego Jana Pawła II, adwokata Stanisława Kłysa, człowieka o wielu talentach, zasłużonego dla świata adwokatury, nauki i Kościoła, razem z ks. Robertem głównych inicjatorów konferencji, prorektorów Jacka Popiela z Uniwersytetu Jagiellońskiego i ks. Wojciecha Misztala z Uniwersytetu Papieskiego Jana Pawła II.

Gorąco pozdrawiam wszystkich profesorów i uczestników z naukowych ośrodków spoza Krakowa, a także artystów, którzy przygotowali niezwykły koncert dla uczczenia piątej rocznicy śmierci metropolity lubelskiego. Jednak w sposób szczególny pragnę pozdrowić brata świętej pamięci Arcybiskupa Józefa - ks. prof. Wojciecha Życińskiego, salezjanina.

Wszystkim słuchaczom życzę naukowej uczty.

Dziękuję! 